\title{
MEASURING VALUE CREATED THROUGH CSR IN REAL ESTATE VALUE CREATION CHAIN
}

\author{
Donatas Jonikas \\ Klaipeda University, Lithuania \\ cross $^{\text {ref }}$ http://dx.doi.org/10.5755/j01.em.19.3.7909
}

\begin{abstract}
This paper presents a conceptual framework for the measurement of value created through corporate social responsibility (CSR). The method of GQM (Basili et al., 1994) was chosen for creating this value measurement framework. The framework takes into account value creation possibilities through all four responsibility types proposed by Carroll (1999) and considers aspects of shared value (Porter and Kramer, 2011). Residential real estate value creation chain (VCC) is developed according to the context of possible CSR initiatives. The suggested framework is proposed as initial tool for value created through CSR measurement in residential real estate VCC. Further adjustments of this framework and residential real estate VCC will be made after surveying experts of CSR and VCC. Development of such framework would allow to measure all value created through CSR independently who has received it - the company, stakeholders or society.
\end{abstract}

The type of the article: Theoretical paper.

Keywords: corporate social responsibility, value creation chain, value measurement, real estate.

JEL Classification: M14, M21.

\section{Introduction}

The problem. There is a discussion in academic society that CSR not always helps to create higher value than its implementation costs. It leads to assumption that implementation of CSR activities might be detrimental for some companies and the whole idea of CSR might not be sustainable enough in practice. But such assumptions can't be reliably verified without measuring all value created through CSR. The residential real estate value creation chain (VCC) only partly adopts CSR (it is noticed that only some actors of this VCC performs CSR activity, while in most cases there is no common CSR policy in the whole VCC). Therefore without a holistic framework for measurement of value created through CSR, it's totally unclear whether residential real estate VCC should foster adoption of CSR.

Having methodology, which enables measurement of value created through CSR in the whole VCC would allow to check the particular cases (like Lithuanian residential real estate VCC) when value created through CSR seems lower than costs of CSR implementation. Such a tool would build a foundation for further research of value creation through CSR and would help to determine reasons why created value might be lower than costs in each particular case. For instance:

1) if wrong CSR initiatives were chosen for implementation;

2) if CSR implementation level has not yet reached the break-even point;

3) if not all value was measured.

The aim of this research is to propose a conceptual framework for measuring the value created through CSR in real estate VCC. 


\section{Method}

The conceptual model for value measurement is developed based on theoretical research and prepared for further verification by survey of experts of CSR and VCC. The method of GQM (Basili et al., 1994) was chosen for creating this value measurement model.

- Objectives and goals for GQM method were adopted from conceptual framework of value creation through CSR in separate member of VCC proposed by Jonikas (2013). Main objectives are to measure value created through CSR and received by company, stakeholders and society. Goals of this method go deeper and describe more specific areas where or to whom the value might be created.

- Questions for the framework where chosen based on acknowledgement that CSR consists of four kinds of responsibilities: economic, legal, ethical, and philanthropy (Carroll, 1999; Aras \& Aybars, 2010; Gholami, 2011; Valackienè \& Micevičienè, 2011). As authors suggested different variables to reveal value in each part of CSR, the range of questions might and should be expanded after surveying experts of CSR and VCC.

- Metrics were found the most challenging part of this framework. There already has been made a distinction between value creation and value appropriation, recognizing that, in some cases, organizations that create new value will lose or will have to share this value with other stakeholders, such as employees, competitors, or society (Nohria \& Ghoshal, 1994; Makadok \& Coff, 2002; Chatain \& Zemsky, 2011; Porter \& Kramer, 2011). Therefore, researching value creation through CSR, Porter and Kramer (2011) suggested the concept of shared value. Four types of value (Jonikas, 2012) should be taken into attention while developing metrics for this framework: not shared exchange, not shared use, shared exchange and shared use value.

Speaking about value creation, an important point of view should be noted that CSR is becoming a business strategy and not only a theory (Juščius, Pukelienè \& Šneiderienè, 2009). Furthermore most of recently performed empiric CSR researches focus on value received by companies. Though, value for stakeholders mostly remains as a secondary topic. Talking about financial value created through CSR, more outstanding view was presented by Visser (2010), Margolis and Walsh (2001) who said that, value creation through CSR is more than just financial profitability. The goal is economic development, which means not only contributing to the enrichment of shareholders and executives, but improving the economic context in which a company operates, including investing in infrastructure, creating jobs, providing skills development and so on. Furthermore company benefits received through CSR could be generally grouped into:

- financial value - Griffin \& Mahon (1997), Margolis \& Walsh (2001), Aras, Aybars, Kutlu (2010), Vyser (2010), Ioannou \& Serafeim (2010).

- competitive advantage - Juščius \& Snieška (2008), Ruževičius \& Serafinas (2007), Georgiev (2009), Quyang (2011), Du, Bhattacharya \& Sen (2010)

- favorable purchase decision making - Hietbrink, Berens \& Rekom (2010), Banyte, Brazioniene, Gadeikiene (2010), Šimanskienė \& Paužuolienè (2010).

Apart those value creation possibilities through CSR, scholars note quite many problems especially related to CSR and stakeholders conjunction. Juščius (2007), Yuan, Bao and Verbeke (2011) pointed the situation that, societal stakeholders' increasingly demand for CSR initiatives, and simultaneous corporate managers require that any such initiatives should improve business performance. Such situation has triggered various alternative strategies to integrate CSR in prevailing business activities, but not all of them are successful. And while there is no holistic framework how to measure value created through CSR, decision making on CSR implementation still remains subjective and one-sided in most cases. 
Table 1. Conceptual framework for measuring value created through CSR

\begin{tabular}{|c|c|c|c|}
\hline Objective & Goal & Questions & Metrics \\
\hline \multirow{11}{*}{$\sum_{0}^{2}$} & \multirow{4}{*}{ Financial } & increased company stock value & stock market price if applicable \\
\hline & & increased sales & change in sales \\
\hline & & loyalty of employees & employee turnover rate, average \\
\hline & & new business activities & opinion of executives (survey) \\
\hline & \multirow{7}{*}{ Marketing } & brand awareness & top of mind position in the market \\
\hline & & positive associations with brand & shift in positive associations \\
\hline & & point of differentiation & opinion of executives and customers \\
\hline & & access to new markets & opinion of executives, factual sales \\
\hline & & customer loyalty and retention & repeat purchase, loyal customer \\
\hline & & favourable purchase decision & customer opinion, sales (if comparable) \\
\hline & & justification of higher price & customer opinion, sales (if comparable) \\
\hline \multirow{11}{*}{ 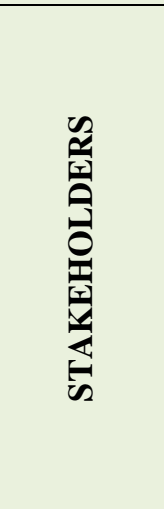 } & \multirow{3}{*}{ Employees } & better work conditions & employee opinion, compliance to standards \\
\hline & & health savings & number of accidents and illnesses \\
\hline & & self - realization and satisfaction & employee opinion (survey) \\
\hline & \multirow{4}{*}{ Customers } & improved quality & $\begin{array}{l}\text { consumer opinion by survey, number or product } \\
\text { return and complaints }\end{array}$ \\
\hline & & higher perceived value & consumer opinion by survey \\
\hline & & new added value & product or service analysis \\
\hline & & involvement (co-creation) & executive opinion, customer opinion \\
\hline & \multirow{4}{*}{$\begin{array}{l}\text { Suppliers and } \\
\text { Business } \\
\text { associates }\end{array}$} & increased competitive advantage & sales, average price, market share \\
\hline & & faster production & production cycle, supply chain timing \\
\hline & & increased mutual trust & opinion of suppliers and partners \\
\hline & & new standard in business sector & case analysis if applicable \\
\hline \multirow{10}{*}{ 気 } & \multirow{4}{*}{ Society } & new social services and products; & case analysis if applicable \\
\hline & & charity projects & received donations and other benefits \\
\hline & & $\begin{array}{l}\text { support for education and job } \\
\text { creation }\end{array}$ & $\begin{array}{l}\text { case analysis if applicable, funds for education } \\
\text { and new job creation, number of new jobs }\end{array}$ \\
\hline & & public health and other welfare & analysis of statistics of specific illnesses \\
\hline & \multirow{2}{*}{ Environment } & prevention of pollution & reduction of $\mathrm{CO}_{2}$ emissions and similar \\
\hline & & restoring contaminated areas & spendings on environment restoration \\
\hline & \multirow{4}{*}{ Government } & budget savings & $\begin{array}{l}\text { alternative costs of government in case if no } \\
\text { such value created }\end{array}$ \\
\hline & & reduced unemployment & $\begin{array}{l}\text { new jobs in CSR companies, government } \\
\text { savings on donations for jobless people }\end{array}$ \\
\hline & & increased GDP & additional GDP created by CSR \\
\hline & & foreign investments & $\begin{array}{l}\text { number of new companies and total investments } \\
\text { when it was done under condition of CSR } \\
\text { adoption }\end{array}$ \\
\hline
\end{tabular}

Theoretical and empiric researches confirm that value creation through CSR is feasible independently to company size particularly on the factors that translate into marketing benefits (Bocquet \& Mothe, 2011; Vancheswaran \& Gautam, 2011). As it is confirmed, small companies can also introduce radical innovation based on their CSR involvement. Results advise that small companies should decide which dimension of CSR is central to their strategy, and how they could use their strategic CSR to develop radical innovation, thus taking advantage of their CSR orientation to further develop value creation and innovation performance. Therefore simple and easily applicable framework for measurement of value creation through CSR would be highly beneficial for small but innovative companies.

As Januszewski (2011) noted in his research, the aim of the identification of key customers is to facilitate the optimal allocation of resources of the company. Not all customers are equally important for the company, and the company is not able and should not try to acquire and satisfy needs of each customer. The same should be said about company stakeholders. Not all of them are equally important for the company, because implementation of CSR initiatives brings different 
value to stakeholder groups. Purely from the economic point of view, the company should adjust its CSR policy towards those stakeholder groups where the largest common value is created at lowest costs of CSR implementation (highest "profit" of CSR implementation independently who will get the largest share of created value).

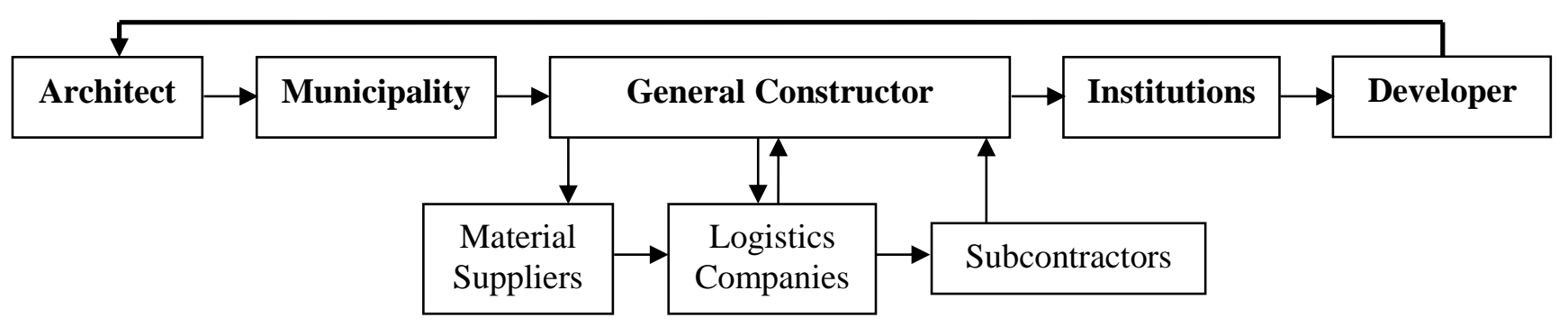

Figure 1. Real Estate Value Creation Chain

Trying to measure value created through CSR in the whole VCC requires defining the VCC, but naming parties of VCC and their interdependencies is not yet enough. Figure 1 shows quite standard VCC in real estate project development. The developer is the company or a person who initiates the real estate project. Developer applies to architect for preparation of the project, which is later confirmed by municipality. After municipality issues construction permission, company starts creation of physical value - constructing a building. Construction company requires various materials from suppliers, logistics company services to deliver those materials and subcontractors for specialized works. Once building is completed, government institutions inspect the object and issue appropriate certificates which validate that building is truly finished, meets all requirements and is ready for use. Finally, developer receives the value - building which is ready for sale, rent or own use.

As it was noted, CSR might help to create not only share, but use value as well. And as it is seen from proposed value measurement framework, not only companies from VCC should be taken under the scope of research, but stakeholders and society as well. Considering all this, much more parties should be taken into account of VCC, while trying to measure value created through CSR in residential real estate VCC.

\section{Results}

Broadening the scope of residential real estate VCC, 4 stages of value creation should be emphasized:

1) pre-construction stage takes all activities before real construction is started (i.e. acquiring land, preparing the project, getting permissions for construction and etc.);

2) construction stage takes all activities which create real physical value (i.e. preparing construction site, ordering and delivering materials, hiring subcontractors and etc.);

3) sales stage takes all activities while ownership of residential real estate is being transferred to new owners - inhabitants (i.e. marketing campaign of residential real estate project, actions of real estate agents, bank credit policy and et.).

4) after-sale stage takes activities which arise after the residential real estate is transferred to new owners (i.e. guarantees for construction work, municipality obligations to develop the district, any issues related to housing credit payment).

Table 2 shows all possible actors of residential real estate VCC which are connected by order flow, information flow, material and service flow, permissions and verifications. Interaction of these actors of VCC is visually show in Figure 2.

Measuring value created through CSR in residential real estate is performed applying framework proposed in Table 1 in all stages of VCC outlined in Figure 2. The received outcome is given in Table 3.

There is no point of measuring increased sales in residential real estate VCC, because each real estate object is new and takes quite long time to be built. Therefore it is suggested to measure if 
such objects are sold faster if they are involved in CSR activity. Customer loyalty and retention is an important benefit and value for company, but it's barely to be possible to measure repeat purchase and loyal customers while analysing sales of residential real estate. Therefore it has been modified to "customer loyalty and recommendations". Though public health and some other welfare is hard to be measured via short period of time, it is left in the new framework for the purpose if this framework might be used for longitudinal research. Foreign investments, as possible outcome of CSR initiatives in residential real estate case, is not likely to be expected, but in any case it is possible.

Table 2. Parties involved in residential real estate VCC

\begin{tabular}{|c|c|c|}
\hline Party of VCC & Role in VCC in context of CSR & $\begin{array}{l}\text { Stage of value } \\
\text { creation }\end{array}$ \\
\hline Project developer & $\begin{array}{l}\text { Investor, project initiator and manager, which makes general } \\
\text { decisions on how real estate project will be developed. It is the } \\
\text { initiator of VCC }\end{array}$ & $\begin{array}{l}\text { pre-construction, } \\
\text { construction, sales }\end{array}$ \\
\hline Land owner & $\begin{array}{l}\text { Can sell or rent land to Project development company. He contributes } \\
\text { to VCC by deciding to support or not to support particular real estate } \\
\text { projects and by setting the price or rent for the land. } \\
\text { Land can be initially owned by: } \\
\text { - project developer } \\
\text { - municipality / government } \\
\text { - other private owner }\end{array}$ & pre-construction \\
\hline Marketer & $\begin{array}{l}\text { This is market researcher, marketing specialist. He determines } \\
\text { business possibilities for real estate and needs of particular market } \\
\text { segments, can suggest CSR initiatives to be added into the project. }\end{array}$ & $\begin{array}{l}\text { pre-construction, } \\
\text { sales }\end{array}$ \\
\hline Architect & Can suggest various project options and ideas related to CSR & pre-construction \\
\hline $\begin{array}{l}\text { Municipality and } \\
\text { related institutions }\end{array}$ & $\begin{array}{l}\text { Municipality not only issues construction permissions, but also can } \\
\text { negotiate with real estate developers for }\end{array}$ & $\begin{array}{l}\text { pre-construction, } \\
\text { after-sales }\end{array}$ \\
\hline State institutions & $\begin{array}{l}\text { Construction inspection institution, Electricity network operator, } \\
\text { Center of registers, Notaries, Mortgage. Even if those institutions } \\
\text { don't create value directly, they act as checkpoints in VCC }\end{array}$ & $\begin{array}{l}\text { pre-construction, } \\
\text { construction, sales }\end{array}$ \\
\hline $\begin{array}{l}\text { Banks or other credit } \\
\text { institutions }\end{array}$ & $\begin{array}{l}\text { Construction financing (loans to project developer, construction } \\
\text { companies and etc.) and loans for flat buyers. Bank's policy and rules } \\
\text { might be responsible or not }\end{array}$ & all stages \\
\hline $\begin{array}{l}\text { Construction } \\
\text { company }\end{array}$ & $\begin{array}{l}\text { Main decision maker and rule setter in construction stage. Tis } \\
\text { company might keep it's CSR policies or not, might require the same } \\
\text { from their subcontractors or not }\end{array}$ & construction \\
\hline Subcontractors & $\begin{array}{l}\text { Construction company hires subcontractors to more specialized } \\
\text { works (i.e. cleaning \& utilization, gardening) and in such cases when } \\
\text { additional help is needed. Subcontractors keep the same CSR } \\
\text { initiatives as main company or not }\end{array}$ & construction \\
\hline $\begin{array}{l}\text { Suppliers of } \\
\text { materials }\end{array}$ & $\begin{array}{l}\text { Materials are healthy and environment friendly or not. Durable and } \\
\text { appropriate quality or not }\end{array}$ & construction \\
\hline Transport & $\begin{array}{l}\text { Prompt delivery of materials to construction site, environment-saving } \\
\text { transportation }\end{array}$ & construction \\
\hline Real estate agents & $\begin{array}{l}\text { Main actors in real estate sales stage. Is the whole sales process } \\
\text { socially responsible or not, mainly depends on them }\end{array}$ & sales stage \\
\hline $\begin{array}{l}\text { Real state evaluation } \\
\text { company }\end{array}$ & $\begin{array}{l}\text { This is independent evaluator of real estate value. Based on these } \\
\text { evaluations banks make decision regarding loans for potential buyers. } \\
\text { Value can be set in ethical way or not }\end{array}$ & sales stage \\
\hline Interior designer & $\begin{array}{l}\text { Can suggest interiors with environment friendly materials, can design } \\
\text { healthier living space and etc. }\end{array}$ & sale, after-sales \\
\hline $\begin{array}{l}\text { Neighbors and local } \\
\text { society }\end{array}$ & If permission for construction is required from neighbors & $\begin{array}{l}\text { pre-construction, } \\
\text { after-sales }\end{array}$ \\
\hline Inhabitants & $\begin{array}{l}\text { Flat buyers for whom CSR initiatives can be important or have no } \\
\text { meaning at all. }\end{array}$ & Sales, after-sales \\
\hline Mass media & $\begin{array}{l}\text { Can announce good or bad news about the project since its initial } \\
\text { stage. Can be used by developer or real estate agent to advertise the } \\
\text { project. }\end{array}$ & $\begin{array}{l}\text { all stages, but } \\
\text { specially in sales } \\
\text { stage }\end{array}$ \\
\hline
\end{tabular}




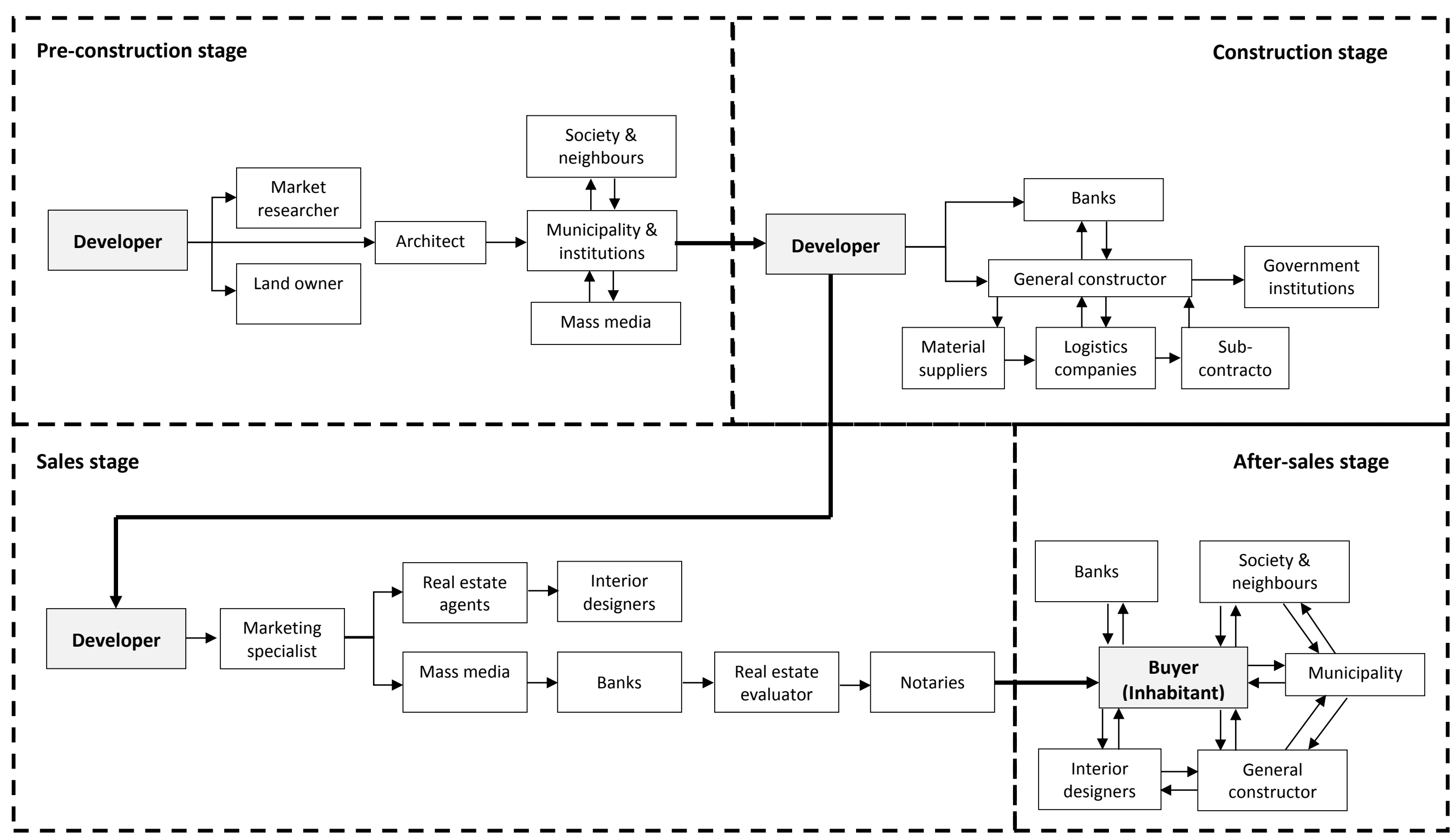

Figure 2. Residential real estate value creation chain in context of CSR 
Table 3. Conceptual framework for measuring value created through CSR in residential real estate VCC

\begin{tabular}{|c|c|c|c|c|c|}
\hline Objective & \multicolumn{2}{|r|}{ Goal } & Questions & Metrics & Method \\
\hline \multirow{12}{*}{$\sum_{0}^{\bar{z}}$} & \multirow{5}{*}{\multicolumn{2}{|c|}{ Financial }} & increased company stock value & stock market price if applicable & Market data \\
\hline & & & faster sales & $\begin{array}{l}\text { average sales time per object (i.e. flat) } \\
\text { object sale out percentage per year }\end{array}$ & Case analysis \\
\hline & & & increased price & $\begin{array}{l}\text { price per } \mathrm{m}^{2} \text { of the real estate object compared to price of similar } \\
\text { type objects without CSR activity }\end{array}$ & Market data \\
\hline & & & loyalty of employees & employee turnover rate, average & Case analysis \\
\hline & & & new business activities & opinion of executives (survey) & Survey \\
\hline & \multirow{7}{*}{\multicolumn{2}{|c|}{ Marketing }} & brand awareness & $\begin{array}{l}\text { top of mind position in the market; } \\
\text { number of times mentioned in the press }\end{array}$ & $\begin{array}{l}\text { Survey Market } \\
\text { data }\end{array}$ \\
\hline & & & positive associations with brand & shift in positive associations & Survey \\
\hline & & & point of differentiation & opinion of executives and customers & Survey \\
\hline & & & access to new markets & opinion of executives, factual sales & Survey \\
\hline & & & customer loyalty and recommendations & $\begin{array}{l}\text { customers opinion if they would recommend to others a real estate } \\
\text { object built by the company }\end{array}$ & Survey \\
\hline & & & favourable purchase decision & customer opinion, sales (if comparable) & Survey \\
\hline & & & justification of higher price & customer opinion, sales (if comparable) & Survey \\
\hline \multirow{11}{*}{ 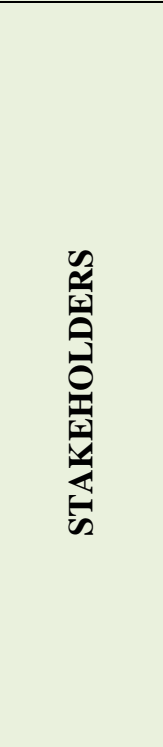 } & \multirow{3}{*}{\multicolumn{2}{|c|}{ Employees }} & better work conditions & employee opinion, compliance to standards & Survey \\
\hline & & & health savings & number of accidents and illnesses & Case analysis \\
\hline & & & job satisfaction and self - realization & employee opinion (survey) & Survey \\
\hline & \multirow{4}{*}{ Customers } & \multirow{4}{*}{$\begin{array}{c}\text { Buyers or tenants of } \\
\text { new flats }\end{array}$} & improved quality & $\begin{array}{l}\text { consumer opinion by survey, number or product return and } \\
\text { complaints }\end{array}$ & Survey \\
\hline & & & higher perceived value & consumer opinion by survey & Survey \\
\hline & & & new added value & product or service analysis & Case analysis \\
\hline & & & customer involvement (co-creation) & executive opinion, customer opinion & Survey \\
\hline & \multirow[b]{4}{*}{$\begin{array}{c}\text { Suppliers and } \\
\text { Business } \\
\text { associates }\end{array}$} & \multirow{4}{*}{$\begin{array}{c}\text { Architect; } \\
\text { Land owner; } \\
\text { Market researcher; } \\
\text { Banks; } \\
\text { General constructor; } \\
\text { Subcontractors and } \\
\text { material suppliers; } \\
\text { Real estate agent; } \\
\text { Interior designers; } \\
\text { Lawyers; }\end{array}$} & increased competitive advantage & sales, average price, market share & Case analysis \\
\hline & & & faster production & production cycle, supply chain timing & Case analysis \\
\hline & & & increased mutual trust & opinion of suppliers and partners & Survey \\
\hline & & & new standard in business sector & case analysis if applicable & Case analysis \\
\hline
\end{tabular}




\begin{tabular}{|c|c|c|c|c|c|}
\hline \multirow{13}{*}{ 式 } & \multirow{4}{*}{ Society } & \multirow{4}{*}{$\begin{array}{l}\text { Neighbours } \\
\text { (directly); } \\
\text { Society (through } \\
\text { mass media) }\end{array}$} & new social services and products; & case analysis if applicable & Case analysis \\
\hline & & & charity projects & received donations and other benefits & Case analysis \\
\hline & & & support for education and job creation & $\begin{array}{l}\text { case analysis if applicable, funds for education and new job } \\
\text { creation, number of new jobs }\end{array}$ & Case analysis \\
\hline & & & public health and other welfare & analysis of statistics of specific illnesses & Market data \\
\hline & \multirow{3}{*}{\multicolumn{2}{|c|}{ Environment }} & prevention of pollution & reduction of $\mathrm{CO}_{2}$ emissions and similar & Case analysis \\
\hline & & & restoring contaminated areas & spending on environment restoration & Case analysis \\
\hline & & & saving nature in other forms & if buildings are planned in the way to save natural surroundings & Case analysis \\
\hline & \multirow{6}{*}{$\begin{array}{l}\text { Government } \\
\& \\
\text { Municipality }\end{array}$} & \multirow{4}{*}{ Government } & budget savings & alternative costs of government in case if no such value created & Case analysis \\
\hline & & & reduced unemployment & $\begin{array}{l}\text { new jobs in CSR companies, government savings on donations for } \\
\text { jobless people }\end{array}$ & Case analysis \\
\hline & & & increased GDP & additional GDP created by CSR & Case analysis \\
\hline & & & foreign investments & $\begin{array}{l}\text { number of new companies and total investments when it was done } \\
\text { under condition of CSR adoption }\end{array}$ & Case analysis \\
\hline & & \multirow{2}{*}{$\begin{array}{c}\text { Construction } \\
\text { inspection institution; } \\
\text { Electricity network } \\
\text { operator; } \\
\text { Real estate evaluator; } \\
\text { Center of registers; } \\
\text { Notaries; }\end{array}$} & \multirow{2}{*}{$\begin{array}{l}\text { if any stimulations is provided from } \\
\text { these institutions to company or any of } \\
\text { stakeholders }\end{array}$} & $\begin{array}{l}\text { research of legal base (if laws or any other documents foresee any } \\
\text { kind of benefits for residential reals estate where CSR is applied) }\end{array}$ & Case analysis \\
\hline & & & & institution's opinion and their official policy & Survey \\
\hline
\end{tabular}




\section{Discussion}

Value creation through CSR is mostly researched only from the perspective of a single company or group of stakeholders, but not holistically in a whole VCC. There are various suggestions on value measurement methodology, but when it comes to measurement of shared or use value, it's difficult to find any methodology convenient enough for practical implementation. The proposed framework is just conceptual idea which will be developed in few ways:

1) any new benefits invoked by CSR implementation should be reviewed and, if needed, added to question section of this framework;

2) there should be added more metrics and rules for their calculation in order to make this framework more objective and precise;

3) system for measurement of use value in practice should be clarified.

Another field of discussion concerns the proposed residential real estate VCC. It should be evaluated by expert survey and updated in such way that it becomes more convenient for practical use, but still remains holistically.

\section{References}

Aras, G., Aybars, A. \& Kutlu, O. (2010). Managing corporate performance: investigating the relationship between corporate social responsibility and financial performance in emerging markets. International Journal of Productivity and Performance Management, Vol. 59, No. 3, 229-254. doi: http://dx.doi.org/10.1108/1741040101 1023573

Banyte, J., Brazioniene, L., Gadeikiene, A. (2010) Expression of Green Marketing Developing the Conception of Corporate Social Responsibility. Inzinerine Ekonomika-Engineering Economics. (5), $550-560$

Basili, V. R. et al. (1994). Goal Question Metric Approach. John Wiley\&Sons

Bocquet, R. \& Mothe, C. (2011). Exploring the relationship between CSR and innovation: A comparison between small and largesized French companies. Revue Sciences de Gestion, Issue 80, 101-119.

Carroll, A. (1999). Corporate social responsibility. Evolution of a definitional construct. Business \& Society, Vol. 38, No. 3, 268-295. doi: http://dx.doi.org/10.1177/000765039903800303

Chatain, O. \& Zemsky, P. (2011). Value creation and value capture with frictions. Strategic Management Journal, Vol. 32, No. 11, 1206-1231. doi: http://dx.doi.org/10.1002/smj.939

Du, S., Bhattacharya, C. B., Sen, S. (2010). Maximizing Business Returns to Corporate Social Responsibility (CSR): The Role of CSR Communication. International Journal of Management Reviews, Vol. 12 Issue 1, 8-19. doi: 10.1111/j.1468-2370.2009.00276.x

Gholami, S. (2011). Value Creation Model through Corporate Social Responsibility (CSR). International Journal of Business and Management Vol. 6, No. 9. doi:10.5539/ijbm.v6n9p148

Griffin, J. J., Mahon, J. F. (1997). The corporate social performance and corporate financial performance debate. Business \& Society, 36, 5. http://dx.doi.org/10.1177/000765039703600102

Hietbrink, J. J. C., Berens, G. \& Renkom, J. (2011). Corporate Social Responsibility in a Business Purchasing Context: The Role of CSR Type and Supplier Product Share Size. Corporate Reputation Review, Winter2011, Vol. 13 Issue 4, 284-300. doi:10.1057/crr.2010.24

Ioannou, I. Serafeim, G. (2010). The impact of corporate social responsibility on investment recommendations. Working Papers, Harvard Business School Division of Research, 1-45. doi:10.2139/ssrn.1507874

Yuan, W., Bao, Y. \& Verbeke, A. (2011). Integrating CSR initiatives in business: an organizing framework. Journal of Business Ethics, Vol. 101, No. 1, 75-92. doi: http://dx.doi.org/10.1007/s10551-010-0710-z

Januszewski, F. (2011). Possible applications of instruments of measurement of the customer value in the operations of logistics companies. Scientific Journal of Logistics. Vol. 7, Issue 4, No 2, $17-25$

Jonikas, D. (2012). Value creation through CSR at stakeholders level. Economics and Management, 2012. 17 (2), 693-698. http://dx.doi.org/10.5755/j01.em.17.2.2200

Jonikas, D. (2013). Conceptual framework of value creation through CSR in separate member of value 
creation chain. Bulletin of Geography. Socio-economic Series No.21, 69-78. http://dx.doi.org/10.2478/bog-2013 -0022

Juščius, V. (2007). Corporate Social Responsibility and Sustainable Development. Organizaciju vadyba: sisteminiai tyrimai. (44), 35-44.

Juščius, V., Jonikas, D. (2013). Integration of CSR into Value Creation Chain: Conceptual Framework. Engineering Economics, Vol 24, No 1. doi http://dx.doi.org/10.5755/j01.ee.24.1.2016

Juščius, V., Pukelienè, V., Šneiderienė, A. (2009). İmonių socialinė atsakomybė tarptautinių kompanijų veikloje. Applied Economics: Systematic Research. Vol. 3 Issue 1, 175-192.

Juščius, V., Snieška, V. (2008). Influence of Corporate Social Responsibility on Competitive Abilities of Corporations. Inzinerine Ekonomika-Engineering Economics(3), 34-44.

Makadok, R. \& Coff, R., 2002: The theory of value and the value of theory: breaking new ground versus reinventing the wheel. Academy of Management Review, Vol. 27, No. 1, 10-13. http://dx.doi.org/10.5465/AMR.2002.5922307

Maltz E., Thompson, F., Jones Ringold, D. (2011). Assessing and maximizing corporate social initiatives: a strategic view of corporate social responsibility. Journal of Public Affairs. Volume 11 Number 4, 344 352. doi: $10.1002 /$ pa.384

Margolis, J. D. \& Walsh, J. P. (2001). People and Profits? The Search for a Link between a Company's Social and Financial Performance. Mahwah, N.J.: Lawrence Erlbaum Associates.

Nohria, N. \& Ghoshal, S. (1994). Differentiated fit and shared values: alternatives for managing headquarters subsidiary relations. Strategic Management Journal, Vol. 15, No. 6, 491-502. doi: http://dx.doi. org/10.1002/smj.4250150606

Ouyang, Y. (2011). An Exploration of LMX and Personal Guanxi on Job Performance: the Mediating Effects of CSR. Journal of Global Business Issues, Vol. 5 Issue 1, 1-10.

Porter, M. E. \& Kramer, M. R. (2011). Creating shared value. Harvard Business Review, Vol. 89, No.1/2,6277.

Ruževičius, J., Serafinas, D. (2007). The Development of Socially Responsible Business in Lithuania. Inzinerine Ekonomika-Engineering Economics, (51), 36-43.

Šimanskienė, L., Paužuolienė, J. (2010). İmonių socialinès atsakomybès svarba lietuvos organizacijoms. Management Theory \& Studies for Rural Business \& Infrastructure Development. Vol. 20 Issue 1, 138145.

Valackienè, A. \& Micevičienė, D., 2011: Methodological framework analysing a social phenomenon: stakeholder orientation implementing balanced corporate social responsibility. Inzinerine EkonomikaEngineering Economics, Vol. 22, No. 3, 300-308. doi: http://dx.doi.org/10.5755/j01.ee.22.3.520

Vancheswaran, A. \& Gautam, V. (2011). CSR in SMEs: Exploring a Marketing Correlation in Indian SMEs. Journal of Small Business and Entrepreneurship, v. 24, iss. 1, 85-98. doi: $10.1080 / 08276331.2011 .10593527$

Visser, W., 2010: The age of responsibility: CSR 2.0 and the New DNA of business. Journal of Business Systems, Governance and Ethics. Vol. 5, No. 3, 7-22. doi: 10.1177/1080569912467225 